July 1984

\title{
Faculty Advisor's Column
}

\author{
Harvey J. Schwartz, MD \\ Thomas Jefferson University Hospital
}

Follow this and additional works at: https://jdc.jefferson.edu/jeffjpsychiatry

Part of the Psychiatry Commons

Let us know how access to this document benefits you

\section{Recommended Citation}

Schwartz, MD, Harvey J. (1984) "Faculty Advisor's Column," Jefferson Journal of Psychiatry. Vol. 2 : Iss. 2 , Article 1.

DOI: https://doi.org/10.29046/JJP.002.2.004

Available at: https://jdc.jefferson.edu/jeffjpsychiatry/vol2/iss2/1

This Article is brought to you for free and open access by the Jefferson Digital Commons. The Jefferson Digital Commons is a service of Thomas Jefferson University's Center for Teaching and Learning (CTL). The Commons is a showcase for Jefferson books and journals, peer-reviewed scholarly publications, unique historical collections from the University archives, and teaching tools. The Jefferson Digital Commons allows researchers and interested readers anywhere in the world to learn about and keep up to date with Jefferson scholarship. This article has been accepted for inclusion in Jefferson Journal of Psychiatry by an authorized administrator of the Jefferson Digital Commons. For more information, please contact: JeffersonDigitalCommons@jefferson.edu. 


\section{FACULTY ADVISOR'S COLUMN}

This issue of our Journal marks a new stage in our development. We have started accepting papers from residency programs other than our own. Encouraged by the enthusiastic response our prior issues have elicited from psychiatric educators around the country, we are embarking on a program of expansion. In doing so we hope to provide a unique arena for psychiatric resident thinking. Residents nationwide are invited to share with each other and their faculties, their discoveries, their uncertainties and the newness with which they view their work.

The breadth of current resident interests is well demonstrated in this issue of the Journal. This includes the interpersonal-intrapsychic dimension of anorexia nervosa, the interface of psychomotor seizures and psychosis, a broad based approach to chronic pain, and brief case reports on the psychiatric presentation of AIDS and a descriptive view of auto-castration. In addition, beginning with this issue we inaugurate our resident Book Review section with a review of David Malan's introductory text on analytic psychotherapy.

The variety of perspectives of these articles brings encouragement to the many in our field who prize what has come to be called the eclectic approach to psychiatry. Others may become concerned lest the treasured and painstakingly studied depth understanding of patients give way to the more readily learned phenomenologic approach to psychopathology. As psychiatric educators it is our responsibility to help our trainees tolerate the affect-filled midway course between the simultaneous temptations of premature conceptual closure on the one hand and smorgasbord superficiality on the other. One way to accomplish this is to recognize the differing levels of abstraction with which alternative paradigms understand mental functioning.

While any of the syndromes presented in this issue may serve as example, Dr. Greenspan's thoughts on the eating disorders nicely demonstrate the multiplicity of views by which a single phenomenon may be studied. They may be viewed as complimentary as long as it is recognized that they represent different levels of conceptualization with their own particular tools of investigation and data bases. We have been repeatedly reminded of this in our own studies in the Jefferson Bulimia Treatment Program as we have been confronted by the variety of approaches currently advocated for this condition. The preliminary findings suggesting a role for antidepressants in this disorder derives from the medical-descriptive model of diseases. It uses as its method of investigation biologic measures of neurotransmitter dysequilibrium, and its therapeutic tools are pharmacologic alteration of chemical deficiencies. Its data base is symptom intensity.

Family studies, as well as simultaneous analyses of mother and symptomatic child, reveal, as Dr. Greenspan notes, the interpersonal dimension to the maintenance of eating disorder symptomotology. The method of investigation and data base in family therapy is based on the cross-generational communication dysfunctions that 
ultimately lead to the child's viewing himself through the distorted vision of his parents, not infrequently as a narcissistic extension of mother. Interventions seek to realign boundaries, redefine individuation and internalize conflict.

The dynamic model studies the latent neurosogenic fantasies and conflicts that are revealed through its data base of metaphor, dreamwork and transference imagery. Its tools are free association, interpretation and the analytic frame. These investigative methods allow for the recovery of the fantasies of infantile sexuality - such as oral impregnation-and identifies the pathologic regression from these guilt-laden wishes.

Our task in education is to teach residents how to gather information from and intervene in all these levels of conceptualization and most importantly to recognize the differences between them. A broadened approach to psychiatric education need not necessarily lead to superficial understanding. A depth appreciation of neurobiology, the methods of interpersonal transmission of pathogenic fantasy, and the ubiquity of intrapsychic drive-defense compromise formation is the goal of modern training. As we welcome our Montefiore colleagues to our readership, we look forward to this Journal both encouraging and demonstrating the vitality of residents' broad based, yet depth understanding of psychopathology.

In the spirit of this endeavor, it is a great pleasure to announce Dr. David Scola's receipt of both the city-wide Kenneth Appel Award and our own Lieberman Award for Excellence in Writing for his paper published in our last issue entitled "The Hemispheric Specialization of the Human Brain and Its Application to Psychoanalytic Principles."

Harvey J. Schwartz, M.D.

Director of Residency Training Faculty Advisor to the Journal 